\title{
Assessment of women food vending and local soap making micro enterprises in Temeke Municipal: A Costs Benefit Analysis approach
}

\author{
Christina Shimba \\ Department of Community Development, \\ Tengeru Institute of Community Development \\ P.0.BOX, 1006, Arusha, Tanzania \\ Kepha Luvinga \\ Department of Project Planning and Management, \\ Tengeru Institute of Community Development, \\ P.0.BOX, 1006, Arusha, Tanzania. \\ Simon A Kilasara \\ Department of Project Planning and Management, \\ Tengeru Institute of Community Development, \\ P.0.BOX, 1006, Arusha, Tanzania.
}

\begin{abstract}
This paper was designed to assess the contribution of women entrepreneurship in improving household livelihood at Temeke municipal council in Dar es salaam region, specifically the study aimed to identify the types and attributes, analyse sustainability of the selected enterprises and assess the contribution of women enterprises to household livelihood in the study area. A sample of 60 women were selected randomly from a list of women entrepreneurs' groups dealing with food vending (40) and local soap making who were 20. Data were collected using structured interview and were coded and entered into computer software. Cost benefit analysis and Sustainable Livelihood Index were used to analyse the viability and contribution of food vending and local soap making enterprises. Results show that the two enterprises were viable, but local soap making is more viable than food vending. Thus it is concluded that innovative enterprises are sustainable and can improve the household livelihood. The paper recommends that the government and other stakeholders should facilitate and motivate women to embark more in innovative enterprises for enhancing their livelihoods.
\end{abstract}

Keywords: Soap making, food vending, enterprise, cost benefit analysis

\section{INTRODUCTION}

Although seen to many as commonplace in Africa, the informal sector plays an extremely significant role in the economy. The informal sector employs the largest share of the workforce, with some studies projecting its contribution at $60 \%$ of the economy. According to the Integrated Labour Force Survey $40 \%$ of all households in Tanzania Mainland were in the informal sector activities (NBS, 2007). The urban informal sector employed 66 percent of the labour force as the main activity. In contrast, rural informal sector employed 34 percent of the labour force as main activity (Wangwe and Mmari, 2013). Having traditionally suffered from restricted access to formal education and formal sector employment to women, selfemployment in the informal sector oftentimes represents the sole option for them. 
The role of entrepreneurship of an entrepreneurial culture in economic and social development has often been underestimated. Over the years, however it has become increasingly apparent that entrepreneurship indeed contributes to economic development nevertheless; the significant numbers of enterprises were owned by men (ILO, 2006) however it was not common to see women owned business worldwide especially in developing countries. The idea and practice of women entrepreneurship is a recent phenomena. Until 1980s little was known about women entrepreneurship both in practice and investigations, which made its focus entirely on men .scientific discourse about women's entrepreneurship and women owned and run organizations is just the development of 1980s (ILO, 2006).

The micro and small scale enterprise (MSE) sector has within the past three decades gravitated into the mainstream within development debates. Research on micro and small scale enterprise (MSE) activities underscores the centrality of the sector as a major source of employment and a way to enhance income streams for the poor (Greeley, 2006; CGAP, 2003). Through numerous self-employment opportunities for the poor, the MSE sector is seen as a means of making the poor economically active.

The volume of activity in the sector and given that these activities are considered as a major source of employment for the poor is evidence of the substantial number of livelihoods that are dependent on these activities. Much of the discussions on MSEs indicate the proliferation of women with the expansion of WMSEs becoming a common phenomenon particularly in developing countries. Whilst women's micro and small scale enterprises (WMSEs) are instrumental in facilitating the economic participation of poor female entrepreneurs, these activities are strategic in meeting basic needs and ensuring household survival as benefits are also directly linked to meeting different household needs in terms of their contributions to healthcare, nutrition, and education (Greeley, 2006; Hashemi, 2004; Mahmud, 2003). This evidence lays the ground for some optimism in the role of WMSE activities as a major source of survival.

\section{Statement of the Problem}

The government of Tanzania has expressed commitment to support women's entrepreneurship through a number of policy pronouncements as well as specific support programmes. The Government of Tanzania has made impressive strides in supporting women entrepreneurs, and its policies reflect a commitment to advancing women (World Bank Group, 2007). Taking note of the fact that women play significant role in family sustenance, the question is are women really better-off or worse-off? This question could be answered by analyzing the situation critically raising a number of issues in women entrepreneurial development. Despite the widely held assumption that women's micro enterprises would lead to transformation of their disadvantaged position in households and society in general, still the viability of the micro women enterprises is not well known in the study area. The focus of this paper is on women micro-entrepreneurship in Temeke municipal selling a typical street food, and those making local soaps. Aside from providing significant income for women entrepreneurs, food vending entrepreneurial activities offer an essential source of inexpensive ready-to-eat food for workers of every class. Moreover, there is scarce empirical evidence on the sustainability of the women micro enterprises.

\section{Theoretical framework}

Micro-enterprise programs generally target self-employed or micro businesses (less than ten employees) that function as part of the informal sector including small production units, street vendors, and transportation service engaged in undocumented and unregulated economic activity (Johnson and Kidder 1999; Mosley and Hulme 1998). While women's self-started 
income generating projects may have been the original target of microenterprise development programs, most of Trinidad's current programs are gender neutral, although women are more likely than men (and this appears to be the trend globally) to use these programs (Grasmuck and Espinal 2000).

It is an informal sector is characterized by ease entry, reliance on indigenous resources, family ownership of enterprise, small scale operation, labour intensive methods of production, skills acquired outside the formal school system and unregulated and competitive markets (ILO, 1972). In the entrepreneurship literature, starting an enterprise is mainly seen from a microeconomic perspective as a decision made by an individual person (Schade and BurmeisterLamp, 2009). In a Global South context, the decision to start an enterprise has to be seen more strongly from a household perspective, as there the household is regarded as a collective unit based on pooled consumption, and is consequently an important unit for collective decision making (de Haas, 2010; Naudé et al., 2009; Byrne, 2001), especially regarding decisions related to their livelihood strategy (Ellis, 2000).

DFID (1999) the Sustainable Livelihood Framework includes all actions undertaken by a household to increase its standard of living are seen as part and parcel of its livelihood strategy (Fox and Sohnesen, 2013). According to Fox (2008), the economic livelihood of a household can be specified by the structure of its income sources. Thus, micro entrepreneurship can be seen as one of the possible economic livelihood strategies existing to households that has the potential to influence the livelihood outcome (Fox and Sohnesen, 2012; DFID, 1999). The term livelihood outcome refers to a household's wellbeing and is commonly measured using the household's income, consumption or vulnerability to poverty (Scoones, 1998).

A livelihood may be defined as comprising the capabilities or tangible and non-tangible assets such as social resources that are required to make a living. Capabilities mean what people are actually able to do with the goods which they possess (Nussbaum, 2003). Not only would capabilities enhance productivity and efficiency, capabilities allow humans to "engage meaningfully and fruitfully with the world and most importantly the capability to change the world" (Bebbington, 1999)

A livelihood may be considered sustainable if a household is able to still earn a living continuously, regardless of external stresses or shocks (Rakodi, 2013). A shock is anything like ever rising inflation or any sudden event such as an early death of a bread winner or a job loss which weakens a household's income or livelihood.

According to Albu and Scott (2001) there are six core Principles of an Sustainable Livelihood approach namely; (i) People centred - starting with people and what matters to them; working with them, and promoting change in the dimensions of poverty which they prioritise. (ii) Holistic - not restricted by boundaries of professional sphere or 'sector', it should consider the multiplicity of actors, influences, strategies and outcomes that shape people's livelihoods (iii) Dynamic - understanding that people's livelihoods and forces which shape them are ever changing, responding flexibly and developing longer-term commitments. (iv) Building on strengths - replacing a focus on 'needs' with one on 'assets'; realising people's latent potential to achieve their own livelihood objectives by removing constraints. (v) Macro-micro links highlighting linkages between poor women and men and the legislative instruments and practices which determine access to assets, define opportunities. (vi) Sustainability - balancing different dimensions such as resilience to negative external forces, dependency on institutions (and in turn their sustainability), non-depletion of natural resources and others' livelihood options. 


\section{Analytical framework}

Several empirical studies have shown the positive effect of participating in micro entrepreneurial activities on the household's wellbeing. For instance, Van de Walle \& Cratty (2004) show that the probability of being poor is lower among Vietnamese households who undertake micro entrepreneurial activities. Moreover, McNamara \& Weiss (2005) find that micro entrepreneurship leads to a more stable household income, and Fox \& Sohnesen (2012) demonstrate that micro entrepreneurship is positively related to increasing household income. These positive effects can be traced back to three main advantages that participation in micro entrepreneurial activities entails. First, micro entrepreneurship is used as a diversification strategy by risk-averse farm households in order to deal with uncertainties linked to price fluctuations in input and output markets, as well as uncertain weather conditions, both of which affect agricultural production. Diversification into non-farm activities can enable households to generate a more stable income and to reduce income risks (McNamara \& Weiss 2005, GRIMM et al. 2012). Second, running a micro enterprise has the advantage of flexible decision-making and adaption of the business activities in times of uncertainty (Mead \& Liedholm 1998). Third, the average revenue that can be generated by selling non-farm products and services is higher than that generated by selling primary agricultural commodities (Song 2012). Hence, it can be assumed that households that choose micro entrepreneurship as a livelihood strategy are able to increase their wellbeing, reduce their vulnerability to poverty and perform better in times of crises.

\section{METHODOLOGY}

This study concentrated on two main micro enterprises that are initiated with small capital by most of women in urban areas of Tanzania. The enterprises are food vending and local handmade soap. The study was conducted in Tandika ward of Temeke Municipality in Dar es Salaam region. Tandika ward was selected randomly from other wards of municipal where there is a growing practice of micro enterprises among women as an intervention for improving household's livelihood. Data were collected at once from the respondents at one point in time basing on the study variables.

\section{Sampling Procedures}

Household survey techniques and case study approaches were used to collect the data required for this study. A minimum of sixty households was selected for each category of the enterprises. Despite the analytical/statistical disadvantages of the small sample, the method was preferred because, close monitoring of women entrepreneurs, for example, measurements of their actual costs and revenue from the enterprises were necessary.

\section{Data collection}

\section{Questionnaire Design}

The basic tool for data collection was structured questionnaires. A set of five questionnaires was prepared to collect data from food vending and local handmade soap, however, the study was extended to cover sampled households livelihood. The questionnaires were slightly different to reflect the differences in nature and operations for each enterprise. Generally, the questionnaires were designed to capture data on input costs and revenues.

\section{Pre-testing}

The questionnaires were pre-tested to ascertain the validity of questions before final administration was made. In each case, six respondents were randomly selected for pre-testing of the questionnaire. Necessary adjustments were made accordingly to improve the questionnaires after the pre-testing exercise. 
Questionnaire administration procedure

Data collection was conducted by researchers and enumerators based in the field. The data for economic analysis were supplemented with data collected using the household survey questionnaire described.

\section{Data Processing and Analysis}

Data analysis was done using Microsoft EXCEL and Statistical Package for Social Sciences;. Entrepreneurial innovations and specifically appraisal of micro-enterprises has received increasing attention in the scientific and policy debates overtime. Different economic methods have been developed to identify and evaluate innovations. From a purely economic perspective, whenever possible a CBA is preferred with respect to the assessment of enterprise options (Vardakoulias, 2014). The technique is also universally used for this purpose (Hallegatte et al., 2011; Chadburn et al., 2010; Chambwera and Stage, 2010). A CBA is basically comparing costs and benefits of an intervention over time (GSF, 2011). The major limitation of a CBA, however, is that all the costs and benefits must be measurable in monetary terms.

$$
B C R=\frac{\sum_{t=1}^{n} R_{t} \frac{1}{(1+r)^{t}}}{\sum_{t=1}^{n} C_{t} \frac{1}{(1+r)^{t}}}
$$

$$
N P V=\sum_{t=1}^{n} R_{t}\left(\frac{1}{(1+r)^{t}}\right)-\sum_{t=1}^{n} C_{t}\left(\frac{1}{(1+r)^{t}}\right)
$$

where:

$B C R=$ Discounted BCR of the practice, $N P V s=$ Net Present Value of an enterprise (TShs),

$R_{t}=$ revenue in year $t$ (TShs), $C_{t}=$ costs in year $t$ (maintenance plus production costs) (TShs), $r=$ discount rate, and $t \ldots n=$ year $t$ to $n^{\text {th }}$ of the enterprise time horizon.

\section{Demographic characteristics of the respondent}

\section{RESULTS AND DISCUSSION}

\section{Age of the respondents}

Due to the data findings result from the area of the field it reveals that respondents aged 20-30 with the percent of $43.3 \%$ were highly more engaged in entrepreneurial activities compared to the respondents aged 51-60 where with the percent of $6.7 \%$. This implies that most women who are entrepreneurs are in the age of youth this proves that there energetic to contribute the gross domestic product of our country and earn something for the household at large.

Table 1: Age of the respondents

\begin{tabular}{lcc}
\hline Age of respondents & Frequency & Percentage \\
\hline $20-30$ & 26 & 43.3 \\
$31-40$ & 20 & 33.3 \\
$41-50$ & 10 & 16.7 \\
$51-60$ & 4 & 6.7 \\
Total & 60 & 100 \\
\hline
\end{tabular}

\section{Marital status of the respondents}

Due to the advancement of technology and due to economic crisis, life has been very hard most areas in urban people live single and they hustle daily to build up life. In this case most women entrepreneurs are single this is shown through the fact that single have the frequency of equivalent of $36.7 \%$, married were represented by $30 \%$. Hence this proves that most women entrepreneurs are single struggling to build their own life 
Table 2: Marital status of respondents

\begin{tabular}{lcc}
\hline Marital status of respondents & Frequency & Percentage \\
\hline Single & 22 & 36.7 \\
Married & 18 & 30.0 \\
Widower & 12 & 20.0 \\
Divorce & 6 & 10.0 \\
Separated & 2 & 3.3 \\
Total & 60 & 100 \\
\hline
\end{tabular}

\section{Education level of respondents}

Results from Table 3 revels that $50 \%$ of respondents from Tandika ward had primary education $20 \%$ had secondary education, and 26.7 had informal education. Therefore this information implies that most women entrepreneurs are primary school leavers and most of them do have informal education hence in ascertaining if the business is worth to be undertaken.

Table 3: Education levels of respondents

\begin{tabular}{lcc}
\hline Level of education & Frequency & Percentage \\
\hline Primary & 30 & 50 \\
Secondary & 12 & 20.0 \\
Higher Learning Education & 2 & 3.3 \\
Informal Education & 16 & 26.7 \\
Total & 60 & 100 \\
\hline
\end{tabular}

\section{Main occupation}

The results shows the main occupation among all respondents, $36.7 \%$ of the sampled respondent involve in business, $23.3 \%$ of the respondents are farmers, self employee are $33.3 \%$ and $6.7 \%$ are employee. This information implies that many respondents in the study area involve themselves in business more than other occupation. However the researcher found that from sampled respondent most of them engaged in other activity such as livestock keeping in order improving household livelihood.

Table 4: main occupation of respondents

\begin{tabular}{lcc}
\hline Respondents occupation & Frequency & Percentage \\
\hline Business person & 22 & 36.7 \\
Farmer & 14 & 23.3 \\
Employee & 4 & 6.7 \\
self employee & 20 & 33.3 \\
Total & 60 & 100 \\
\hline
\end{tabular}

\section{Household size}

Due to the findings most respondents are living alone they claim that life is a challenging task so they opt to live alone so as they can sustain in improving their own household livelihood ,however the respondents claimed that even if they live with 1-5 with the percent of 26.7, then followed by 4-6 with the percent of 20\%, while, 7-15 with the percent of 6.7. Therefore due to this findings women entrepreneurs choose to live alone claiming that life is very hard so they need to prepare themselves properly to ensure proper household livelihood to the coming generation.

Table 5: Household size

\begin{tabular}{lcc}
\hline Respondents household size & Frequency & Percentage \\
\hline $1-5$ & 16 & 26.7 \\
$4-6$ & 12 & 20.0 \\
$7-15$ & 4 & 6.7 \\
None & 28 & 46.6 \\
Total & 60 & 100 \\
\hline
\end{tabular}




\section{Source of capital}

Due to the research findings the Table 6 shows that $56.7 \%$ had their own source of capital, where some who acquires from relatives with frequency of 12 equivalents to $20 \%$ and financial institution having $17.1 \%$ where $3.3 \%$ claim to get capital from their husband, Hence it signifies that women are more awake to reduce poverty this is proven where the rate of having their own source of capital is greater than depending from their relatives that means wherever they get opportunity to get capital they use it perpendicularly to start business.

Table 6: sources of capital

\begin{tabular}{lcc}
\hline Source of capital & Frequency & Percentage \\
\hline My own source & 34 & 56.7 \\
From ma relatives & 12 & 20.0 \\
My husband & 2 & 3.3 \\
Loan from financial institution & 12 & 20.0 \\
Total & 60 & 100 \\
\hline
\end{tabular}

From the findings it can be denoted that sources of capital for those activities/projects initiated by women came from their own sources of income and few from their relatives and financial institutions such as SACCOS, bank and only a single from their husband this signifies that women are more awake and they no longer depend from other people for help, hence provision of household needs and affordable livelihood is assured.

\section{Starting capital}

From the research findings most business capital for women reveal $50 \%$ of the respondent starting capital was between 10,000-60,000 shillings, $26.7 \%$ of respondent starting capital was between $70,000-100,000$ shillings where $16,7 \%$ of respondent their starting capital was $1,100,000-1,500,000$ shillings and $6.6 \%$ of respondents starting capital was between 1,600,000 to $3,000,000$ shillings as Table 7 shows.

Table 7: The business starting capital

\begin{tabular}{lcc}
\hline AMOUNT CAPITAL & Frequency & Percentage\% \\
\hline $10,000-60,000$ & 30 & 50 \\
$70,000-100,000$ & 16 & 26.7 \\
$1,100,000-1,500,000$ & 10 & 16.7 \\
$1,600,000-3,000,000$ & 4 & 6.6 \\
Total & 70 & 100.0 \\
\hline
\end{tabular}

Results also show that many women started their business with low capital about 10,00060,000 this was due to inability to access loan from financial institution since it requires details that are specific but it also proves that women are more awake about the issue of poverty and they are willing and able to be creative and innovative so as to ensure household needs are met.

\section{Annual profitability of the enterprises}

Table 8 shows the comparison of the two enterprises namely the Handmade soap and Food vending. The results indicates that Handmade soap had profit margin of 1,439,025.00 while the Food vending enterprise has profit margin of 806,400.00 Tanzania shillings (See table 8 for details). This implies that, the soap making products are more profitable in the first year production as compared to the food vending services.. 
Table 8: Annual profitability of the enterprises

\begin{tabular}{|l|c|c|}
\hline \multirow{2}{*}{ Items } & \multicolumn{2}{|c|}{ Enterprise } \\
\cline { 2 - 3 } & Handmade soap & Food vending \\
\hline Total costs & $12,240,975.00$ & $50,798,400.00$ \\
\hline Total Revenue & $13,680,000.00$ & $51,604,800.00$ \\
\hline Profit & $\mathbf{1 , 4 3 9 , 0 2 5 . 0 0}$ & $\mathbf{8 0 6 , 4 0 0 . 0 0}$ \\
\hline
\end{tabular}

\section{Viability of the enterprise (projects)}

Like any other enterprise every enterprise has its own worthiness and viability. To measure this we need to have the discounted cash flow, showing the net present value and the benefit costs ratio (BCR) as discounted measures to assess the project sustainability, for women project the study used the discounted measures since it takes into account time value for money.

Discount cash flow investigation is a method of valuing a project, business, or asset using the concepts of the time value of money. All future cash flows are estimated and discounted by using cost of capital to give their present values (PVs). The sum of all future cash flows, both incoming and outgoing, is the net present value (NPV), which is taken as the value or price of the cash flows in question. The study used $15 \%$ as a discounting factor due to the fact that it is the discounting rate adopted by the Bank of Tanzania (BOT) and the study used the projection of 7 years to assess whether the project is worth and viable to be undertaken.

\section{Appraisal of liquid handmade soap and food vending}

There are three methods of calculating BCR but the most common used is by taking the discounted gross benefits divide by total discount gross cost. The decision rule is to accept the Projects with $\mathrm{BCR}$ greater than one (BCR $>1$ ) and reject projects with BCR less than one (BCR $<1)$.

Table 9: Benefit cost analysis for the enterprises

\begin{tabular}{lll}
\hline BCA & Liquid handmade soap & Food vending \\
\hline BCR & 1.73 & 1.33 \\
NPV & $12,816,804.02$ & $2,935.643 .15$ \\
\hline
\end{tabular}

Table 9 shows that the BCR for the two enterprises were greater than one. Therefore the two enterprises can be accepted as far as BCR is concerned. Moreover, the net present value (NPV) of the enterprises were also positive implying that the enterprises are profitable (financially and economically viable).

However, benefit cost analysis does not capture potential changes in factors that alter the profitability of enterprises, in other words the analysis does not consider risks and uncertainties. This means that the BCR and NPV are subject to change with changes in market prices for inputs and outputs. To test whether study's results are stable or unstable as a result of the above changes, sensitivity analysis is recommended. The main assumption is that one factor can be is changed at a time. The results of sensitivity analysis are presented in Table 10.

Table 10: Sensitivity Analysis

\begin{tabular}{lcccc}
\hline Sensitivity Analysis & \multicolumn{2}{c}{$\begin{array}{c}\text { Liquid handmade soap } \\
\text { (innovative) }\end{array}$} & \multicolumn{2}{c}{ Food vending (conventional) } \\
\cline { 2 - 5 } & NPV & BCR & NPV & BCR \\
\hline Base & $12,816,804$ & 1.73 & $2,935.643 .15$ & 1.33 \\
Decline in sales price by 10\% & $7,949,462$ & 1.48 & $913,738.33$ & 1.18 \\
increase in operating expenses by & $12,331,114$ & 1.69 & $1,996,615.72$ & 1.24 \\
$10 \%$ & & & & \\
\hline
\end{tabular}


For liquid handmade soap enterprise; an increase in average production costs by $10 \%$ the BCR and NPV signifies viability of the project (Table 10). Likewise a ten percent decrease in product price did not alter the viability of the measures of project worth. The results also suggest that liquid handmade production is more sensitive to changes in product prices than input prices. However, production remains viable when the suggested changes are made. Meanwhile, the food vending enterprise; an increase in average production costs and decline in the average market prices of the selected food by 10\%, results into measures of enterprise worth still remains viable (Table 10). As the case for liquid handmade soap food vending enterprises were also more sensitive in sales price change than input cost change.

When the two types of enterprises compared using BCR; the innovative (liquid handmade soap) enterprises were more viable than the conventional (food vending) enterprises. This suggests that the innovative enterprises are more profitable than conventional enterprises (food vending), because the conventional enterprises have stiff competition as it is ease to enter or penetrate in the enterprise for majority of the entrepreneurs.

\section{Contribution of the enterprises in improving household Livelihood}

The study went further to investigate the contribution of the micro enterprises in enhancing livelihoods at household level, basing on the five livelihood assets, namely; human, physical, financial, personal and social assets, as suggested by DFiD (1999).

A radar of analysis distributed the assets into five points as Figure 1 reveals. Results show that Human assets (HA) has high rank which is 0.24 (24\%) (Figure 1). This proves that the enterprises have positive contributions on all aspects of human assets such as health.

Figure 1; The contribution of the enterprises to household livelihood

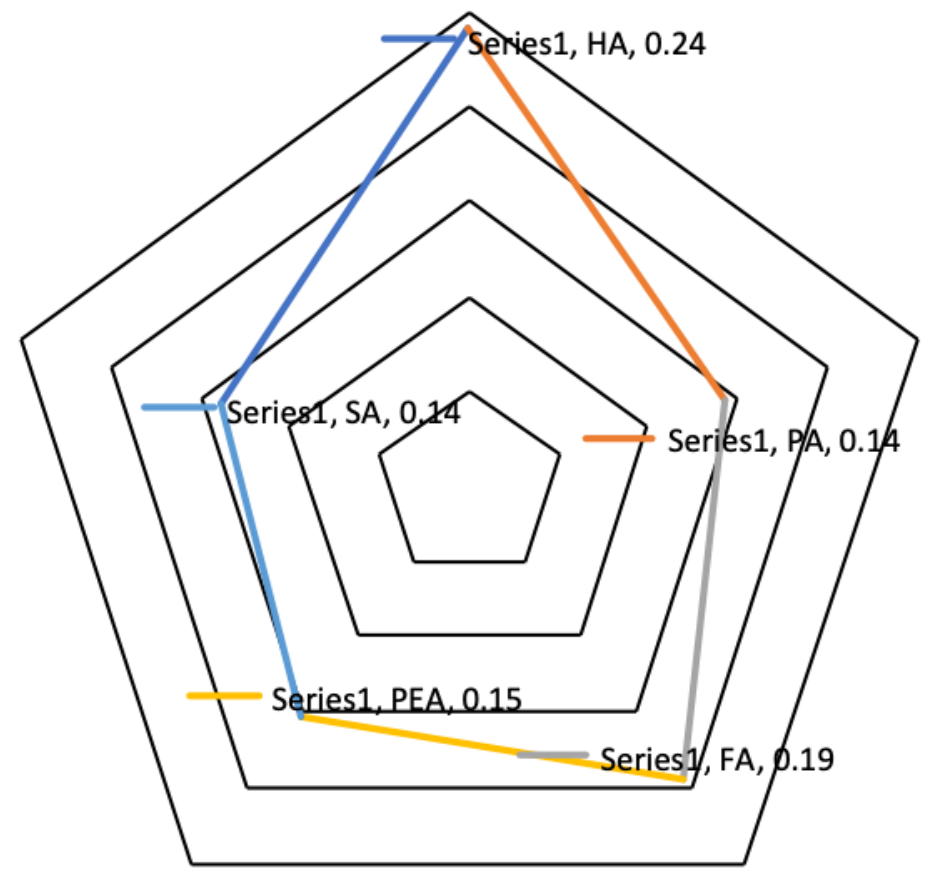

The findings reveals that food vending and Local handmade soap undertaken by women had impact to financial asset with the value of 0.19 (19\%), and it is ranked number 2 . This proves that entrepreneur activities have positive impact on income and productive activity, access to 
credit from other financial institutions, access to clean and affordable energy, or access to productive tools and equipment .

Table 11: livelihood analysis

\begin{tabular}{lcc}
\hline Livelihood Asset & Normalized value & Rank \\
\hline Human Assets & 0.24 & 1 \\
Financial Assets & 0.19 & 2 \\
Personal Assets & 0.15 & 3 \\
Physical Assets & 0.14 & 4 \\
Social Assets & 0.14 & 5 \\
\hline
\end{tabular}

Mean $=17 \%$, Median $=15 \%$ and Standard deviation $=4 \%$

The findings reveals that the enterprises contributes to Personal asset with the normalized value of $0.15(15 \%)$, with the rank of number 3 (Table 11) this proves women entrepreneurs activities provides opportunities on personal improvement and increase people's confidence to start new business with minimum capital Therefore years to come women will be more awake in doing activities that will add a great domestic product to the country (GDP)

The Physical assets (PA) normalized value was $0.14(14 \%)$ and ranked $4^{\text {th }}$ among the livelihood assets. Here women entrepreneurs have access on both child secure shelter, clean and affordable energy, information accessibility Example phone TV, radio, access of basic consumer needs from shops, market, and groceries. Social asset (SA) also scored 0.14 (14\%). This shows that the food vending and local handmade sop have impact on various elements of social assests such as community connectedness, interaction on various matters pertaining the community, family support, friendship among the community members hence this shows how the women entrepreneurial activities have created a huge social relationships among members. All in all the mean of the values of the assets normalized was $17 \%$, signifying that there is a little improvement in the assets due to the enterprise establishment, despite the fact that the project were viable. This may be contributed by small size of the enterprise, small capital, time frame since the projects were established (infant stage).

Therefore towards enhancing livelihood women entrepreneurs activities still helps in human asset only such as acquiring skills on business, leadership employability and earning power .this is proven through looking the average of $17 \%$ after computing livelihood analysis.

\section{CONCLUSION}

Based on the existing potential for innovative enterprises and the profitability of the related products, it is concluded that innovativeness in micro and small enterprises should be prioritized so as to achieve the National development Vision 2025 of Tanzania as a middle income country. This is because such innovativeness can be a source of market for raw materials produced by farmers and other productive sectors. Enterprises are potential for poverty reduction and minimizing unemployment problem to most of the youth. Moreover, the increase in return to investment and the favourable performance of the benefit cost analysis show that there is an improvement in the means of the household livelihood.

\section{References}

Albu, M. and Scott, A. (2001). Understanding livelihoods that involve micro-enterprise: markets and technological capabilities in the SL framework, Understanding livelihoods that involve micro-enterprise: markets and technological capabilities in the SL framework, Warwickshire, UK.19.

APEC Small and Medium Enterprises Working Group (2008), Models for supporting women's micro-enterprise development; Best practices and Guidelines APEC publication Terrace Singapore. 
Bebbington, A. (1999). Capitals and Capabilities: A Framework for Analysing Peasant Viability, Rural Livelihoods and Poverty. World Development 27:12 2021-2044.

Benerias L (2006), Micro-enterprise financial Africa entrepreneurship and small business Dar es Salaam DUP Itd.

Bertrand, I. (2010), Innovation and Entrepreneurship: New Themes for Women Times. Annals of Innovation and Entrepreneurship, Editorial 2010, 1: 5657.

de Beer, (2013). The informal economy, innovation and intellectual property - Concepts, metrics and policy considerations. Economic Research Working Paper No. 10,Geneva.

Fapohunda, T. (2012). Women and the Informal Sector in Nigeria: Implications for Development.

Grasmuck, Sherri and Rosario Espinal. (2000). "Market Success or Female Autonomy? Income, Ideology, and Empowerment among Microentrepreneurs in the Dominican Republic." Gender and Society 14:231-255.

Human Development Report (1997), Women as Entrepreneurs a formal and informal economy, Singapore.

ILO, (1972). Employment, Incomes and Equality: A Strategy for Increasing Productivity and Employment in Kenya. Geneva

Johnson, Susan and Thalia Kidder. (1999). "Globalization and Gender-Dilemmas for Microfinance Organizations." Small Enterprise Development 10: 4-15.

Kothari C.D (2004): Research Methodology; Methods and Techniques. New Age International Publishers Limited, New Delhi, India

Kweka J, Kabelwa G, and Musa J, (2006), A background for Tanzania case study of the UTSS, Project on trade development and poverty (TDP)

Maleko C (2005), Impact of electricity services on micro enterprises in rural areas in Tanzania.

Mosley, P. and D. Hulme. (1998). 'Microenterprise Finance: Is There a Conflict Between Growth and Poverty Alleviation?' World Development 26: 783-790.

National Bureau of Statistics, 2007. The Integrated Labour Force Survey 2006, Dare es Salaam

Nussbaum, M. (2003). Capabilities as Fundamental Entitlements: Sen and Social Justice. Feminist Economics, 9: 2$333-59$.

OECD (2004), $2^{\text {nd }}$ conference minister responsible for small and medium sized enterprises (SMEs) promotion entrepreneurship and innovative SMEs in global

Olomi, D (2006), Unleashing entrepreneurial potential of the poor in Tanzania: Prospects challenges and ways forward working paper for presentation to the high level commission on legal empowerment of the poor.

Rakodi, C. 2013. A Livelihood Approach: Conceptual Issues and Definitions. In Rakodi, C. \& Lloyd-Jones, T. (Eds) Urban Livelihoods: A People Centred Approach to Reducing Poverty. London: Earthscan.

Vandderchueren E, Wegelin and Wekwete K (1996), Programme option for urban poverty reduction: Framework for action at the municipal level, Washington DC.

Wangwe S. and Mmari, D. (2007). Promoting Micro and Small Enterprises for Inclusive Development: Managing the Transition from Informal to Formal Enterprises. Working paper presented at REPOA's $19^{\text {th }}$ Annual Research Workshop held on April 09-10at the Ledger Plaza Bahari Beach Hotel, Dar es Salaam, Tanzania.United Nation (2005), Investigation in the development a practical plan to Archive Millennium Development Goal, New York.

World Bank Group (2007). Voices of Women Entrepreneurs in Tanzania. International Finance Corporation, Washington, D.C. 36pp. 